\title{
Evaluation of Body Mass Index as a Factor of Outcome in Coronary Artery Bypass Surgery
}

\author{
Mohammad Jahangir Alam¹, Imran Ahmed ${ }^{1}$, Razia Begum², \\ Kazi Al- Hosne Jamil ${ }^{1}$, Shahriar Moinuddin ${ }^{1}$ \\ ${ }^{1}$ Department of Cardiac Surgery, NICVD, Dhaka, ${ }^{2}$ General Hospital, Comilla
}

\begin{abstract}
Keywords: Ischaemic heart disease, Obesity, Coronary artery bypass surgery.
\end{abstract}

\begin{abstract}
:
Background: Obesity is supposed to be a risk factor for patients undergoing coronary artery bypass surgery $(C A B G)$ increasing risk of in-hospital mortality and postoperative morbidity. So, this study was conducted to evaluate the outcome of CABG in obese patients in Bangladesh.

Methods: This prospective clinical trial was undertaken in the Department of Cardiac Surgery, National Institute of Cardiovascular Diseases, Dhaka, Bangladesh from January 2015 to December 2016. A total of 60 consecutive patients were selected for CABG operation and their outcome measured against pre-set variables. Body mass index (BMI) $25 \mathrm{~kg} / \mathrm{m}^{2}$ was considered as cut off value between obese and non-obese patients.

Results: Mortality after CABG surgery was $9.5 \%$ in obese group and $10.3 \%$ in non-obese group $(p=0.976$ ) showing no significant difference but average hospital stay was more in obese group $(10.2+25$ days) than non-obese group $(8.3+3.7$ days), $p=0.489$. Sternal would infection $(50.0 \% \& 8.69 \%)$ and conduit harvest site infection $(35.7 \% \& 4.34 \%)$ is also more in obese group but not significant statistically $(p=0.064 \& 0.084$ respectively).

Conclusion: Patients with a BMI higher than normal are not at greater risk of in-hospital mortality after CABG. But obese patients should be more cared in post operative period for sternal and conduit harvest site infection as infection is more in obese patients.
\end{abstract}

(Cardiovasc. j. 2018; 10(2): 150-157)

\section{Introduction:}

Ischemic heart disease (IHD) is the most common form of heart disease and the most important cause of premature death in developed countries. ${ }^{1}$ In the UKI in 3 men and I in 4 women die from IHD, an estimated 333,000 people have a myocardial infarct each year and approximately 1.3 million people have angina. The death rates from the IHD in the UK are amongst the highest in Western Europe (more than 140,000 people in 1997) but are falling, particularly in younger groups. In the last 10 years mortality has fallen by $42 \%$ among UK men and women aged 16-64 years. According to the WHO data published in April 2011 Coronary Heart Disease Deaths in Bangladesh reached 163,769 or $17.11 \%$ of total deaths. Bangladesh ranks 25th position in the world in respect to cause of death due to coronary artery disease. ${ }^{2}$ Disease of the coronary artery is almost due to atheroma and its complications, particularly thrombosis.

Worldwide, the prevalence of obesity has taken an epidemic forms; over a billion people are overweight and 300 million people are obese. Eight percent (8\%) females and $10 \%$ males of AMI patients are obese in Bangladesh. Hypertension, diabetes and hyperlipidaemia are common in obese patients in both male and female with no significant sex difference. ${ }^{3}$

Obesity is supposed to be a risk factor for patients undergoing CABG. It is assumed that obesity increases the risk of in-hospital mortality and postoperative morbidity. ${ }^{4}$ The Parsonnet risk stratification scoring system gives a score of 3 points for patients with a body mass index (BMI) of greater than $35 \mathrm{~kg} / \mathrm{m}^{2} .{ }^{4} \mathrm{~A}$ fair number of severely obese patients with coronary artery disease are therefore not referred by cardiologist and have their operations either postponed and are advised to lose weight, or are sometimes even turned down by surgeons due to perceptions of the

supposedly high risk involved when undergoing CABG. However, there does not appear to be much evidence in the literature to support the

Address of correspondence: Dr. Mohammad Jahangir Alam, Department of Cardiac Surgery, National Institute of Cardiovascular Diseases, Dhaka, Bangladesh. Email:jahangircts@gmail.com 
assumptions that obese patients have poor outcome compared to non- obese patients after CABG.

In recent years, there has been data published from several institutions suggesting that the risks of undergoing $\mathrm{CABG}$ in obese patients may be no different than in the non-obese, especially with regards to mortality; although an increased risk of wound infections and atrial fibrillation have been highlighted. ${ }^{5}$

However, the relationship of obesity and the risk of adverse outcomes after CABG is still unclear due to small number of patients in several of this studies. ${ }^{6}$ So further study about the effect of BMI on CABG are time worthy.

\section{Methods:}

This prospective clinical trial was conducted in the Department of Cardiovascular Surgery of National Institute of Cardiovascular Diseases, Dhaka, Bangladesh during the period from January 2015 to December 2016. This nonrandomized clinical study consisted of sixty consecutive patients with coronary artery bypass surgery and were divided into two groups, Group A - obese (BMI $\geq 25 \mathrm{~kg} / \mathrm{m}^{2}$ ) and Group B- non obese $\mathrm{BMI}<25 \mathrm{~kg} / \mathrm{m}^{2}$ ) on the basis of their BMI in accordance with Asian ethnicity. Patients having ischaemic heart diseases with valvular diseases, pulmonary diseases, impaired renal function, ejection fraction $<40 \%$, age $>70$ years, $\mathrm{BMI}<18.5 \mathrm{~kg} / \mathrm{m}^{2}$ and redo-coronary artery surgery were excluded from the study. Ethical consideration was strictly maintained with upholding patient's best interest.

Patients were selected after having matched the inclusion and exclusion criteria. Weight and height were measured and recorded in all participants by a standard medical scale and stadiometer, respectively. All the methods adopted to measure height and weight was standard referring to Richard EB et al ${ }^{7}$ Self reported weight and height was not accepted. BMI was calculated, categorized and recorded accordingly. Coronary Artery Bypass Surgery was done with standard conventional technique in all patients. In hospital outcomes were observed and recorded with one month followup data along with it. Each patient's outcomes were measured against postoperative ventilation time, ICU stay, hospital stay, neurological problem, perioperative MI, re-intervention, renal problem, sternal wound infection, conduit harvest site infection, pulmonary complications and in-hospital mortality. Statistical analysis was done using standard method with t test and chisquare test. Statistical significance was assumed if $p<0.05$ throughout the study.

\section{Results:}

\section{Distribution of Age and Sex:}

Out of 60 patients the mean age was $50.5 \pm 8.0$ years ranging from 35 to 68 years. The mean age of group A patients was $50.0 \pm 7.6$ years ranging from 37 to 61 years and group $B$ patients were $50.8 \pm 8.3$ years ranging from 35 to 68 years. Analysis revealed that no statistically significant $(p>0.05)$ mean age difference was found between group A and B patients in unpaired t-test.

Out of 60 patients, male female ratio was $9: 1$. In group A 18(85.7\%) and group B 36(92.3\%) was male and the rest $3(14.3 \%)$ and $3(7.7 \%)$ was female in group A and group B respectively. Analysis revealed that no statistically significant $(p>0.05)$ difference was found between the groups regarding male and female ratio.

Table-I

Age distribution of the study population.

\begin{tabular}{lcccc}
\hline Age in years & Group A $(\mathrm{n}=21)$ & Group B $(\mathrm{n}=39)$ & Total $(\mathrm{n}=60)$ & $\mathrm{p}$ value \\
\hline Mean \pm SD & $50.0 \pm 7.6$ & $50.8 \pm 8.3$ & $50.5 \pm 8.0$ & 0.863 \\
Range & 37 to 61 & 35 to 68 & 35 to 68 & \\
\hline
\end{tabular}

Group A: Obese patients $\left(\mathrm{BMI} \geq 25 \mathrm{~kg} / \mathrm{m}^{2}\right)$

Group B: Non-obese patients (BMI $\left.<25 \mathrm{~kg} / \mathrm{m}^{2}\right)$

$\mathrm{P}$ value reached from unpaired t-test

$\mathrm{ns}=$ Not Significant 
Table-II

Sex distribution of study population.

\begin{tabular}{|c|c|c|c|c|c|}
\hline \multirow[t]{2}{*}{ Sex } & \multicolumn{2}{|c|}{ Group A $(\mathrm{n}=21)$} & \multicolumn{2}{|c|}{ Group B $(n=39)$} & \multirow[t]{2}{*}{$\mathrm{p}$ value } \\
\hline & no & $\%$ & no & $\%$ & \\
\hline Male & 18 & 85.7 & 36 & 92.3 & $0.417^{\mathrm{ns}}$ \\
\hline Female & 3 & 14.3 & 3 & 7.7 & \\
\hline
\end{tabular}

Group A: Obese patients (BMI $\left.\geq 25 \mathrm{~kg} / \mathrm{m}^{2}\right)$.

Group B: Non-obese patients (BMI $\left.<25 \mathrm{~kg} / \mathrm{m}^{2}\right)$.

$\mathrm{p}$ value reached from Chi square test.

ns $=$ Not Significant

\section{Distribution of other preoperative patient characteristics:}

The mean BMI of the study patients was $24.9 \pm 3.20 \mathrm{~kg} / \mathrm{m}^{2}$ ranging from 19.37 to $32 \mathrm{~kg} / \mathrm{m}^{2}$. The mean BMI of group A patients was $28.5 \pm 2.28$ $\mathrm{kg} / \mathrm{m}^{2}$ ranging from 25 to $32 \mathrm{~kg} / \mathrm{m}^{2}$ and group B patients was $22.9 \pm 1.4 \mathrm{~kg} / \mathrm{m}^{2}$ ranging from 19.37 to $24.99 \mathrm{~kg} / \mathrm{m}^{2}$. Analysis revealed that statistically significant $(p<0.05)$ mean BMI difference was found between group A and B patients in unpaired t-test.

In group A12 patients (57.1\%) had hypertension, $8(38.1 \%)$ had diabetes and $13(61.9 \%)$ had dyslipidaemia. In group B 5(12.8\%) had hypertension, $6(15,4 \%)$ diabetes and $4(10.3 \%)$ dyslipidaemia. Analysis revealed that statistically significant $(p<0.05)$ difference was found between group A and group B patients in chi square test in term of hypertension and dyslipidaemia. Regarding the LV function was observed that $13(61.9 \%)$ good and rest $8(38.1 \%)$ moderate in group A. In group B 30(76.9\%) was good and rest 9(23.1\%) moderate in group $\mathrm{A}$. Analysis revealed that no statistically significant ( $p>0.05$ ) difference was found between group A and group B patients in chi square test.

Regarding extent of coronary disease, single vessel was none in both groups. Double vessel was 5(23.8\%) and 9(23.1\%) in group A and group B respectively. Triple vessel was $16(76.2 \%)$ and $30(76.9 \%)$ in group A and group B respectively. Analysis revealed that no statistically significant $(p>0.05)$ difference was found between group A and group B patients in chi square test.

Postoperative sternal wound infection in Diabetic and Non-diabetic patient was 6 (42.9\%) and $5(10.9 \%)$ respectively. Post operative conduit harvest site infection in diabetic patient was $4(28.5 \%)$ and in non-diabetic patient, it was $3(6.5 \%)$. Analysis revealed that there was statistically significant difference $(p<0.05)$ in postoperative sternal wound infection between diabetic and non-diabetic patient butconduit harvest site infection was not increased significantly in diabetic group.

Perioperative myocardial infarction in hypertensive patients and in normotensive patients were $1(5.8 \%)$ and $3(6.9 \%)$ respectively. Analysis revealed that there was no statistically significant difference $(p>0.05$ in perioperative myocardial infarction between hypertensive and normotensive patient.

Dyslipidaemia in diabetic and in non-diabetic group was $7(50 \%)$ and 10(21.7\%) respectively. Analysis revealed that there was statistically

\section{Table-III}

Distribution of body mass index in study population.

\begin{tabular}{lcccc}
\hline BMI & Group A $(\mathrm{n}=21)$ & Group B $(\mathrm{n}=39)$ & Total $(\mathrm{n}=60)$ & $\mathrm{p}$ value \\
\hline Mean \pm SD & $28.5 \pm 2.28$ & $22.9 \pm 1.4$ & $24.9 \pm 3.20$ & $0.001^{\mathrm{s}}$ \\
Range & $25-32$ & $19.37-24.99$ & $19.37-32$ & \\
\hline
\end{tabular}

Group A: Obese patients (BMI $\geq 25 \mathrm{~kg} / \mathrm{m}^{2}$ )

Group B: Non-obese patients (BMI $<25 \mathrm{~kg} / \mathrm{m}^{2}$ )

$\mathrm{P}$ value reached from unpaired t-test

$\mathrm{s}=$ Significant 
Table-IV

Distribution of associated preoperative patient characteristics in both groups.

\begin{tabular}{|c|c|c|c|c|c|}
\hline \multirow[t]{2}{*}{$\overline{\text { Variable }}$} & \multicolumn{2}{|c|}{ Group A $(n=21)$} & \multicolumn{2}{|c|}{ Group B $(n=39)$} & \multirow[t]{2}{*}{$\mathrm{p}$ value } \\
\hline & No & $\%$ & no & $\%$ & \\
\hline Hypertension & 12 & 57.1 & 5 & 12.8 & $0.001^{\mathrm{s}}$ \\
\hline Diabetes & 18 & 38.1 & 6 & 15.4 & $>0.05^{\mathrm{ns}}$ \\
\hline Dyslipidaemia & 13 & 61.9 & 4 & 10.3 & $0.001^{\mathrm{s}}$ \\
\hline Good & 13 & 61.9 & 30 & 76.9 & $0.218^{\mathrm{ns}}$ \\
\hline Moderate & 8 & 38.1 & 9 & 23.1 & \\
\hline
\end{tabular}

Group A: Obese patients (BMI $\left.\geq 25 \mathrm{~kg} / \mathrm{m}^{2}\right)$.

Group B: Non-obese patients $\left(\mathrm{BMI}<25 \mathrm{~kg} / \mathrm{m}^{2}\right)$.

$\mathrm{p}$ value reached from chi square test

$\mathrm{S}=$ Significant

$\mathrm{ns}=$ Not Significant

Table-V

Distribution of Extent of Coronary disease in both groups of study population.

\begin{tabular}{|c|c|c|c|c|c|}
\hline \multirow{2}{*}{$\begin{array}{l}\text { Extent of Coronary } \\
\text { disease }\end{array}$} & \multicolumn{2}{|c|}{ Group A $(n=21)$} & \multicolumn{2}{|c|}{ Group B $(n=39)$} & \multirow[t]{2}{*}{$p$ value } \\
\hline & No & $\%$ & no & $\%$ & \\
\hline Single vessel & 0 & 0.0 & 0 & 0.0 & $0.594^{\mathrm{ns}}$ \\
\hline Double vessel & 5 & 23.8 & 9 & 23.1 & \\
\hline Triple vessel & 16 & 76.2 & 30 & 76.9 & \\
\hline
\end{tabular}

Group A: Obese patients (BMI $\left.\geq 25 \mathrm{~kg} / \mathrm{m}^{2}\right)$.

Group B: Non-obese patients (BMI $\left.<25 \mathrm{~kg} / \mathrm{m}^{2}\right)$.

$\mathrm{P}$ value reached from chi square test

$\mathrm{ns}=$ Not Significant

Table-VI

Distribution of patients with wound infection in diabetic and non-diabetic patients

\begin{tabular}{|c|c|c|c|c|c|}
\hline \multirow[t]{2}{*}{$\overline{\text { Variable }}$} & \multicolumn{2}{|c|}{ Diabetic $(\mathrm{n}=14)$} & \multicolumn{2}{|c|}{ Non-diabetic $(\mathrm{n}=46)$} & \multirow[t]{2}{*}{$\mathrm{p}$ value } \\
\hline & no & $\%$ & no & $\%$ & \\
\hline Sternal wound infection & 6 & 42.9 & 5 & 10.9 & $<0.05^{\mathrm{s}}$ \\
\hline Conduit harvest site infection & 4 & 28.5 & 3 & 6.5 & $>0.05^{\mathrm{ns}}$ \\
\hline
\end{tabular}

Diabetic patients

Non-diabetic patients

$\mathrm{P}$ value reached from Fisher exact test

$\mathrm{s}=$ Significant

$\mathrm{ns}=$ Not Significant

\section{Table-VII}

Distribution of perioperative myocardial infarction in hypertensive and normotensive patients.

\begin{tabular}{|c|c|c|c|c|c|}
\hline \multirow[t]{2}{*}{ Variable } & \multicolumn{2}{|c|}{$\begin{array}{c}\text { Hypertensive } \\
\text { patient }(\mathrm{n}=17)\end{array}$} & \multicolumn{2}{|c|}{$\begin{array}{l}\text { Normotensive } \\
\text { patient }(\mathrm{n}=43)\end{array}$} & \multirow[t]{2}{*}{$p$ value } \\
\hline & no & $\%$ & no & $\%$ & \\
\hline $\begin{array}{l}\text { Perioperative myocardial } \\
\text { infarction }\end{array}$ & 1 & 5.8 & 3 & 6.9 & $0.683^{\mathrm{ns}}$ \\
\hline
\end{tabular}


Table-VIII

Showing the distribution of dyslipidaemia in diabetic and non-diabetic patients.

\begin{tabular}{lcccccc}
\hline Variable & \multicolumn{2}{c}{ Diabeticn=14 } & & \multicolumn{2}{c}{ Non-diabeticn=46 } & p value \\
\cline { 2 - 3 } \cline { 5 - 6 } & no & $\%$ & & no & $\%$ & \\
\hline Dyslipidaemia & 7 & 50 & 10 & 21.7 & $0.046^{\mathrm{s}}$ \\
\hline
\end{tabular}

Diabetic patient

Non-diabetic patient

p value reached from Fisher exact test

$\mathrm{s}=$ Significant

significant difference $(\mathrm{p}<0.05)$ regarding dyslipidaemia between diabetic and non-diabetic patient.

Out of 60 patients, mortality was found $2(9.5 \%)$ and $4(10.3 \%)$ in group A (obese) and group B (non-obese) respectively and the difference was not statistically significant $(p>0.05)$ between group A and group B patients in chi square test.

The mean ventilation time (hour) of group A patients was $18.2 \pm 9.3$ hours ranging from 7 to 85 hours and group B patients was $13.2 \pm 4.5$ hours ranging from 5 to 96 hours. Analysis revealed that no statistically significant $(p>0.05)$ mean ventilation time difference was found between group A and B patients in unpaired ttest.

The mean ICU stay (days) of group A patients was $5.5 \pm 2.1$ days ranging from 2 to 11 days and group B patients was $6.2 \pm 3.7$ days ranging from
2 to 20 days. Analysis revealed no statistically significant $(p>0.05)$ regarding mean ICU stay period.

The mean hospital stay (days) of group A patients was $10.2 \pm 62.5$ days ranging from 5 to 15 days and group B patients was $8.3 \pm 3.7$ days ranging from 6 to 21 days. Analysis revealed that no statistically significant $(p>0.05)$ mean hospital stay difference was found between group $\mathrm{A}$ and $B$ patients in unpaired t-test.

In group A patients, morbidity was found $3(14.3 \%)$ neurological problem, $2(9.5 \%)$ peri operative MI, $1(4.8 \%)$, re intervention, $2(9.5 \%)$ renal problem, $7(33.3 \%)$ sternal wound infection, $5(23.8 \%)$ harvest site infecton, $1(4.8 \%)$ pulmonary problem. In group B patients, morbidity was found $3(7.7 \%)$ neurological problem, 2(5.1\%) peri operative MI, $1(2.6 \%)$ re intervention,3(7.7\%) renal problem, 4( 10.3\%)

Table-IX

Mortality of study population after $C A B G$.

\begin{tabular}{|c|c|c|c|c|c|}
\hline \multirow[t]{2}{*}{ Variable } & \multicolumn{2}{|c|}{ Group A $(n=21)$} & \multicolumn{2}{|c|}{ Group B $(\mathrm{n}=39)$} & \multirow[t]{2}{*}{$p$ value } \\
\hline & no & $\%$ & no & $\%$ & \\
\hline Mortality & 2 & 9.5 & 4 & 10.3 & $0.976^{\mathrm{ns}}$ \\
\hline
\end{tabular}

Group A: Obese patients (BMI $\left.\geq 25 \mathrm{~kg} / \mathrm{m}^{2}\right)$. Group B: Non-obese patients $\left(\mathrm{BMI}<25 \mathrm{~kg} / \mathrm{m}^{2}\right)$

$\mathrm{p}$ value reached from chi square test.ns $=$ Not Significant

Table-X

Ventilation time of patients after $C A B G$.

\begin{tabular}{lccc}
\hline & $\begin{array}{c}\text { Group A }(\mathrm{n}=21) \\
(\text { Mean } \pm \text { SD) }\end{array}$ & $\begin{array}{c}\text { Group B }(\mathrm{n}=39) \\
(\text { Mean } \pm \text { SD) }\end{array}$ & p value \\
\hline Ventilation time in hours & $18.2 \pm 9.3$ & $13.2 \pm 4.5$ & $0.265^{\text {ns }}$ \\
ICU stay & $5.5 \pm 2.1$ & $6.2 \pm 3.7$ & $0.289^{\text {ns }}$ \\
Hospital stay & $10.2 \pm 2.5$ & $8.3 \pm 3.7$ & $0.489^{\text {ns }}$ \\
\hline
\end{tabular}

Group A: Obese patients (BMI $\left.\geq 25 \mathrm{~kg} / \mathrm{m}^{2}\right)$.

Group B: Non-obese patients $\left(\mathrm{BMI}<25 \mathrm{~kg} / \mathrm{m}^{2}\right)$.

$\mathrm{P}$ value reached from unpaired t-test 
Table-XI

Distribution of past operative morbidity after CABG in both groups.

\begin{tabular}{|c|c|c|c|c|c|}
\hline \multirow{2}{*}{$\begin{array}{l}\text { Variable } \\
\text { value }\end{array}$} & \multicolumn{2}{|c|}{ Group A $(n=21)$} & \multicolumn{2}{|c|}{ Group B (n=39) } & \multirow[t]{2}{*}{$\mathrm{p}$} \\
\hline & no & $\%$ & no & $\%$ & \\
\hline NeurologicalProblem & 3 & 14.3 & 3 & 7.7 & $0.458^{\mathrm{ns}}$ \\
\hline Perioperative MI & 2 & 9.5 & 2 & 5.1 & $0.515^{\mathrm{ns}}$ \\
\hline Reintervention & 1 & 4.8 & 1 & 2.6 & $0.651^{\mathrm{ns}}$ \\
\hline Renal problem & 2 & 9.5 & 3 & 7.7 & $0.807^{\mathrm{ns}}$ \\
\hline Sternal wound infection & 7 & 33.3 & 4 & 10.3 & $0.064^{\mathrm{ns}}$ \\
\hline Harvest site infection & 5 & 23.8 & 2 & 5.1 & $0.084^{\mathrm{ns}}$ \\
\hline Pulmonary problem & 1 & 4.8 & 2 & 5.1 & $0.450^{\mathrm{ns}}$ \\
\hline
\end{tabular}

Group A: Obese patients (BMI $\left.\geq 25 \mathrm{~kg} / \mathrm{m}^{2}\right)$

Group B: Non-obese patients $\left(\mathrm{BMI}<25 \mathrm{~kg} / \mathrm{m}^{2}\right)$

$\mathrm{p}$ value reached from chi square test

$\mathrm{ns}=$ Not Significant

sternal wound infection, 2(5.1\%), harvest site infection, 2(5.1\%) pulmonary problem and the difference was not statistically significant ( $>0.05)$ between group A and group B patients in chi square test.

\section{Discussion:}

Obesity is considered to be a major risk factor in patients undergoing CABG surgery. A high BMI $\left(\mathrm{BMI}>25 \mathrm{~kg} / \mathrm{m}^{2}\right)$ and especially obesity $\left(\mathrm{BMI}>30 \mathrm{~kg} / \mathrm{m}^{2}\right.$ is attended with the presentation of co-morbidity, like cardiovascular disease, diabetes mellitus, dyslipidemia, hypertension etc. With increasing BMI, the comorbidity increases. Obesity also alters the pulmonary function leading to an increase in functional residual capacity and a decrease in vital capacity and maximum voluntary ventilation. $^{7}$

On the other hand, in several score system, obesity is not identified as a variable needed for risk stratification. ${ }^{9}$ Several recent publications suggest that obesity has no influence on the mortality although there is an increased risk of in-hospital and early postoperative morbidity after CABG surgery.

In this study, the mean age in non obese group requiring $\mathrm{CABG}$ is slightly lower than obese group but statistically it is not significant. This result is more or less similar to other series. ${ }^{10}$ ${ }^{12}$ A male preponderance was observed in both obese and non-obese groups with overall male female ratio of 9:1. In other series, obese patients

were more likely to be men but this series does not support that statement. ${ }^{13}$

In this study, obese patients were more likely to be hypertensive and have dyslipidaemia compared to non-obese patients. In non-obese group, only $12.8 \%$ were hypertensive with dyslipidaemia in $10.30 \%$. Analysis revealed statistically significant difference between obese and non obese group in term of hypertension and dyslipidaemia. This observation concurs with other studies. ${ }^{10}$ In this series, preoperative patient characteristics in the form of extent of coronary disease showed no statistically significant difference between obese and nonobese group.

This study has shown that obesity was not a risk factor for in-hospital mortality. In obese group, mortality was $9.5 \%$ with $10.3 \%$ mortality in nonobese group. This is in concurrence with other studies. ${ }^{6,14-}{ }^{16}$ Prabhakar et al. ${ }^{17}$ found a significant increase for in-hospital mortality in obese patients who had a BMI higher than 35 $\mathrm{kg} / \mathrm{m}^{2}$. He found that moderate obesity (BMI> $35 \mathrm{~kg} / \mathrm{m}^{2}$ ) was associated with a slight but statistically significant increase in risk adjusted increase in mortality and those with extreme obesity $\left(\mathrm{BMI}>40 \mathrm{~kg} / \mathrm{m}^{2}\right)$ had a nearly $50 \%$ increase in risk adjusted mortality. But in this study, there was no study population having BMI $35 \mathrm{~kg} / \mathrm{m}^{2}$. So relationship between moderate obesity und mortality could not be assessed. Here, mild obesity may be protective to stress response and give energy in postoperative 
period. ${ }^{11}$ This study found that obesity only increases the risk of wound infections but statistically it is not significant. There is no increased risk of any other form of morbidity among obese patients undergoing CABG compared to non-obese patients except hospital stay which is more in obese patients but not significant statistically.

In this series, sternal wound infection is present in $33.3 \%$ patients of obese group compared to 10.3 of non-obese patients. It is statistically not significant. Regarding conduit harvest site infection, $23.8 \%$ obese patients developed infection whereas in non-obese group infection developed in $5.1 \%$ of patients. The difference of infection between two group statistically significant $(\mathrm{p}$ value $=0.084)$.

The increase in wound infections was also found in other studies. ${ }^{15-18} \mathrm{~A}$ previous study found that obesity is an independent preoperative risk factor for sternal wound complications after CABG. ${ }^{19}$ This is in association with $\mathrm{Lu} \mathrm{CY}$ et al. ${ }^{20}$ and Schwann et al. ${ }^{5}$ Schwann suggests that this higher risk of wound infections may be due to a decreased perfusion of adipose tissue and increased incidence of diabetes in obese patients. ${ }^{5}$ There is also a relative increase in operating time in obese patients. This suggests an increased open-chest exposure to the environment and may result in an increased incidence of sternal wound infections. My study suggested that there is an association between diabetes mellitus and postoperative wound infection after coronary artery bypass surgery.

This study did not reveal any a significant difference for perioperative myocardial infection, neurological problem, re-intervention, renal problem or pulmonary problem. In obese group, morbidity was found in the form of $14.3 \%$ neurological problem, $9.5 \%$ peri-operative MI, $4.8 \%$ re-intervention, $9.5 \%$ renal problem, $4.8 \%$ pulmonary problem. In the non-obese group neurological problem was $7.7 \%$, perioperative MI $5.1 \%$, reinter-vention $2.6 \%$, renal problem $7.7 \%$, pulmonary problem 5.1\%. Except pulmonary problem all are a little more in obese group but statistically not significant. This study is in concurrence with other studies. ${ }^{6}$ This showed that dyslipidaemia was more in diabetic patient
(50\%) compared to non-diabetic patient where it was $21.7 \%$ and the difference was statistically significant.

Ventilation time was found more in obese group with mean duration of $18.2+9.3$ hours compared to non-obese group where mean duration of mechanical ventilation was $13.2 \pm 4.5$ hours but it is statistically not significant. It is like results of other studies. ${ }^{11}$ Prolong duration of mechanical ventilation could be due to impaired respiratory function as a result of relatively decreased vital capacity and a prolonged depression of respiratory drive due to slow release of anaesthetic agents stored in fatty tissue into the blood stream. ${ }^{18}$ Duration of ICU stay and hospital stay showed no significant difference between two groups. In obese group, mean ICU stay was $5.5 \pm 21$ days with mean hospital stay of $10.2 \pm 2.5$ days. In non-obese group, the mean duration of ICU and hospital stay were $6.2 \pm 3.7$ days and $8.3 \pm 3.7$ days respectively. A little more hospital stay in obese group may be due to the direct effect of increased wound infections in obese group. But this is not statistically significant.

All patients were followed up for one month in this study consisting of written survey directed to all patients who survived. In this survey survival / mortality and non-fatal cardiac events were registered. Non-fatal cardiac events included a new MI, return of angina pectoris, congestive cardiac failure, rhythm disturbance and stroke. But no events were positive in both obese and non-obese groups and hence statistical analysis was not possible. All patients of this study who survived remained fine for one month follow up period.

\section{Study Limitation:}

Several limitations of this study should be addressed. First of all, all the surgeries in both groups were not performed by one surgical team but same protocol was followed by all team and in all cases (off pump coronary artery bypass). The study population was small. If it was a large scale study, it would be more representative. Due to small population, correlation of diabetes mellitus, hypertension, dyslipidaemia and post operative infection in obese and non obese patient also was not so representative. 


\section{Conclusion:}

This study has shown that patients who have a body mass index (BMI) higher than normal are not at greater risk of in-hospital mortality after coronary artery bypass surgery compared with non-obese patients. However, these patients appear to have a greater but statistically insignificant risk of wound infections. Diabetic patients are also at increased risk of postoperative sternal wound infection. So, obese patients can safely undergo coronary artery bypass surgery.

\section{Conflict of Interest - None.}

\section{References:}

1. Boon NA, Fox KAA, Bloomfield P. Disease of Cardiovascular System. In: Da-vidson's principles and practice of Medicine, 19th ed. Chrurchill Livingstone, UK, 2002: 424 .

2. World health rankings 2012, live longer live better (2012), Available at: http://www.worldlifeexpectancy.com/countryhealth- profile/bangladesh [Accessed 14March 2016].

3. Momenuzzaman NAM. A comparative study of risk factors and complications of acute myocardial infarction in females with those in males. MD, Thesis (Car-diology) NICVD1996; 82.

4. Parsonnet V, Dean D, Bernstein AD. A method of uniform stratification of risk for evaluating the results of surgery acquired adult heart disease. Circulation 1989; 79:13-112.

5. Schwann TA, Habib RH, Zacharias A, Parentaeu GL, Riordan CJ, Durham SJ, et al. Effects of body size on operative, intermediate and long term outcomes after coronary artery bypass operation. Ann thorac Surg 2001; 71: 521-531.

6. Brandt M, Harder K, Walluscheck KP, Schottler J, Ratimi A, Moller F, et al. Severe obesity does not adversely affect perioperative mortality and morbidity in coronary artery bypass surgery. Eur J Cardiothorac Surg 2001; 19: 662666.

7. Richard EB. Growth and Milestone of Development. In: Nelson Text Book of Pae-diatrics. 17th ed. Saunders publications, Philadelphia, Pennsylvania, USA, 2004: 332334.

8. Jenkins SC, Moxham J. The effects of mild obesity on lung function. Respir Med 1991; 85:309-311.
9. Nashef SAM, Roques F, Michel PGE, Lemeshow S, Salamon R. European sys-tem for cardiac operative risk evaluation (Euroscope). Eur J Cardiothorac Surg1999; 16:9-13.

10. Moutlton MJ, Creswell LL, Mackey ME, Cox JL, Rosenbfoom M. Obesity is not a risk factor for significant adverse outcomes after cardiac surgery. Circulation 1996; 94: 87-92.

11. Birkmeyer NJO, Charlesworth DC, Hernandez F, Leavitt BJ, Massin CAS, Morton JR, et al. Obesity and risk of adverse outcomes associated with coronary artery bypass surgery. Circulation 1998; 97: 1689-1694.

12. Kim J, Hammar N, Jackobsson K, Leupker RV, McGovern $\mathrm{PG}$, Invert T. Obesity and the risk of early and late mortality after coronary artery bypass graft surgery. Am Heart $J$ 2003; 146:555-560.

13. Reeves BC, Ascione R, Chamberlain MH, Angelini GD. Effect of body mass index on early outcomes in patients understanding coronary artery bypass surgery. J Am Coll Cardiol 2003; 42:668-676.

14. Wouters CW, Noez L, Verheugt FWA, Brouwer RMHJ. Preoperative prediction of early mortality and morbidity in coronary bypass surgery. Cardiovasc Surg 2002; 10: 500-05.

15. Prasad US, Waltker WS, Sang CTM, Campanella C, Cameron EWJ. Influence of obesity on the early and long term results of surgery for coronary artery disease. Eur $J$ Cardiothorac Surg1991; 5:67-73.

16. Engelman DT, Adans DH, Byrne JG, Aranki SF, Callins JJ, et al. Impact of body mass index and albumin on morbidity and mortality after cardiac surgery. $J$ Thorac Cardiovsc Surg 1999;118:867-873.

17. Prabhakar G, Haan CK, Peterson ED, Coombs LP, Cruzzavala JL, Murry GF. The risk of moderate and extreme obesity for coronary artery bypass grafting and outcomes. Ann Thorac Surg 2002; 74:1125-1131.

18. Kuduvalli M, Grayson AD, Fabri BM, Rashid A. The effect of obesity on mid term survival following coronary artery bypass surgery. Eur J Cardiothorac Surg 2003; 23:368373.

19. Noyez L, Van Druten JAM, Mulder J, Schroen M, Skotnicki H, Brouwer MHJ. Sternal wound complications after primary isolated myocardial revascularization. Eur J Cardiothorac Surg 2001; 10:471-476.

20. Lu CY, Grayson D, Tha P, Srinivasan K, Fabri M. Risk factors for sternal wound infection and mid term survival following coronary artery bypass surgery. Eur $J$ Cardiothorac Surg 2003; 23:943-949. 